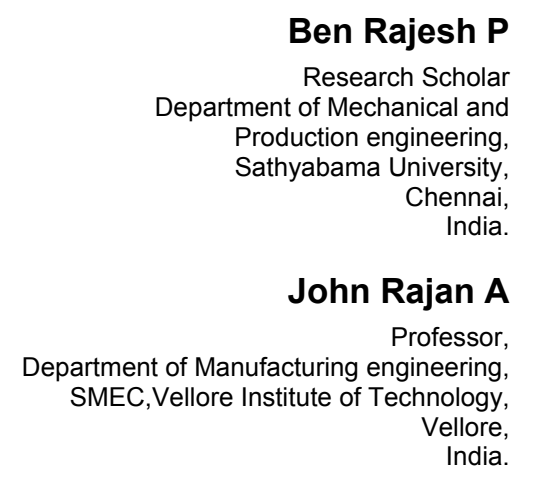

Ben Rajesh P

Research Schola iversity ennai,

$\mathbf{A}$ ellore, India.

\section{Sustainable Performance of Cargo Bikes to Improve the Delivery Time Using Traffic Simulation Model}

Urban freight sector in India witnesses the exponential usage of cargo bikes since 2011, for reaching its customers. Cargo bikes are used by eretail firms for mobility in traffic dense roads. This research contributes to the sustainable development of e-commerce and it measures the economic, environmental and social efficiency of cargo bikes in e-retail firms using survey method. It also estimates the optimum volume of cargo bikes on city roads for effective and timely delivery. Data collected by video graphic study is analysed by a traffic simulation tool 'PTV Vissim'. Simulation results are validated with the real data. The findings of this research helpto replace mini trucks with cargo bikes, which in turn minimizes the delivery time, carbon emission, and driver discomfort. The major implications of this research are: e-retail firms have to motivate its customers to prefer prepaid orders and delivering the goods at non-peak time to achieve sustainability.

Keywords: Cargo bikes, Traffic simulation, Improving delivery time, sustainable development.

\section{INTRODUCTION}

Travel demand is a motivational term [1] of every trip. This demand is highly dynamic and some of the influential demands are: faster delivery of goods to the customers (e-commerce transaction), desire of travel to the employment areas, schools and hospitals. Moreover, trips generated are mainly classified into: personal trips and commercial trips, irrespective of vehicles used. The entire hierarchical network is captured below (Fig-1).

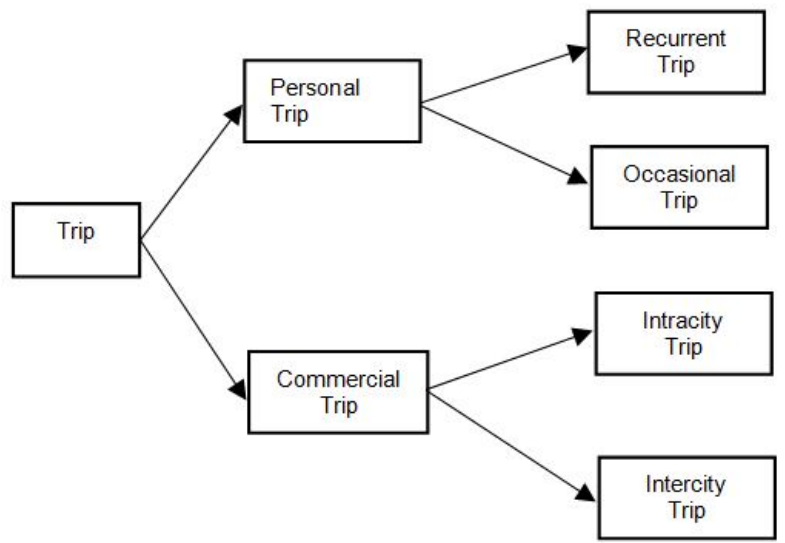

Figure 1. Classification of trips

Personal trip is planned and executed by an individual, with intent of reaching a destination for a specific need (eg. Picnic to hill station; Business trip). Personal trip is sub-divided into recurrent and occasional trip, wherein recurrent trip is a shuttle trip between

Received: December 2019, Accepted: February 2020

Correspondence to: Dr John Rajan A, Department of Manufacturing Engineering, School of Mechanical Engineering, VIT university, Vellore, India

E-mail: ajohnrajan@gmail.com

doi:10.5937/fme2002411R

(C) School of Mechanical Engineering, India. All rights reserved
point-A \& point-B on every day (eg. Job-home/ Schoolhome transit) and an occasional trip is a less frequent travel for a special need (eg. A hospital visit for meeting a doctor). But a commercial trip is organized by a logistic planner, on the basis of customers demand and cargo travel length. It is mainly sub-divided into intracity trip (within city) and intercity trip (connecting two cities). The former one (intracity trip) demands the uni-mode (cargo bikes/trucks) for a full-length trip whereas the latter one executes bi/tri-mode of the transport (bi=truck+rail; tri=truck + rail + truck).

Eventually, the economy of trip performance would be assessed by several factors such as minimal road use price (toll), parking cost, fuel price, maintenance cost, environmental cost (sound and air pollution), quick transit in narrow lane width. It assists e-commerce companies (about 95\%) to decide optimal logistic modes (cargo bikes) for last mile delivery within city zones. Based on the literature survey, there is a need for studying the intra-city trips of cargo bikes as they are economical and pollution free. The objectives of this research are to investigate the potential solutions for the following research questions:

- How far the cargo bikes are green \& sustainable for the regional logistics?

- What is the limit of significance in every key factor to improve the cargo delivery time?

\subsection{LITERATURE REVIEW}

The growing challenges of urban mobility [2] were: scarce road space, shrinked parking spaces due to lane width extension, traffic congestion on peak times, restricted freight storage space had kept the logistic companies in hunger for determining the alternate modes of city transport. Normally, e-commerce companies transported cargo through three types of 
vehicles namely: Cargo bikes, Light vehicles and heavy vehicles. Cargo bikes were the customized bikes used for cargo transit with the engine cylinder size of more than $100 \mathrm{cc}$. Its dimensions can also be modified based on the distance travelled and the quantity of cargo; whereas minitrucks (less than $1000 \mathrm{cc}$ ) were sorted as light vehicles and cargo vans (greater than $1000 \mathrm{cc}$ ) were termed as heavy vehicles.

Table-1: Major Literature On Cargo Bikes

\begin{tabular}{|c|c|c|c|c|}
\hline AUTHOR & YEAR & $\begin{array}{c}\text { CITY \& } \\
\text { COUNTRY }\end{array}$ & $\begin{array}{c}\text { RESEARCH } \\
\text { OBJECTIVES }\end{array}$ & KEY RESULTS \\
\hline $\begin{array}{c}\text { Handy et } \\
\text { al [5] }\end{array}$ & 2012 & US & $\begin{array}{l}\text { What are the key } \\
\text { factors } \\
\text { considered for } \\
\text { mode of } \\
\text { transport? }\end{array}$ & $\begin{array}{l}\text { The significant } \\
\text { factors considered } \\
\text { for mode selection } \\
\text { are: travel } \\
\text { behavior, built } \\
\text { environment } \\
\text { (infrastructure), } \\
\text { attitudes, gender- } \\
\text { response } \\
\text { differences. }\end{array}$ \\
\hline $\begin{array}{c}\text { Melo et al } \\
{[6]}\end{array}$ & 2011 & $\begin{array}{l}\text { Porto, } \\
\text { Portugal }\end{array}$ & $\begin{array}{l}\text { What is the } \\
\text { impact of cargo } \\
\text { cycles on traffic } \\
\text { energy } \\
\text { efficiency and } \\
\text { carbon emissions } \\
\text { in urban } \\
\text { environment? }\end{array}$ & $\begin{array}{l}\text { The optimum } \\
\text { replacement of } \\
\text { delivery vans by } \\
\text { cargo cycles and } \\
\text { bikes would lead to } \\
\text { better road } \\
\text { efficiency and } \\
\text { reduce carbon } \\
(\mathrm{CO} 2) \text { emissions } \\
\text { and cost. }\end{array}$ \\
\hline $\begin{array}{l}\text { Arnold et } \\
\text { al [7] }\end{array}$ & 2018 & $\begin{array}{l}\text { Antwerp, } \\
\text { Belgium }\end{array}$ & $\begin{array}{l}\text { How can } \\
\text { different } \\
\text { delivery modes } \\
\text { have compared } \\
\text { and assessed for } \\
\text { efficacy before } \\
\text { deployment? }\end{array}$ & $\begin{array}{l}\text { Cargo bikes used } \\
\text { for last mile } \\
\text { delivery had } \\
\text { following impacts: } \\
\text { Driving time } \\
\text { increases upto } \\
134 \% \text { in the zone } \\
\text { of outside the city } \\
\text { limits whereas the } \\
\text { external costs } \\
\text { reduced to } 40 \% \\
\text { per parcel. }\end{array}$ \\
\hline $\begin{array}{c}\text { Choubassi } \\
{[8]}\end{array}$ & 2015 & $\begin{array}{c}\text { Netherlands } \\
\text {, Dutch; } \\
\text { Newyork, } \\
\text { US; London } \\
\text { UK. }\end{array}$ & $\begin{array}{l}\text { What is the area } \\
\text { of use for cargo } \\
\text { bikes in urban } \\
\text { areas? }\end{array}$ & $\begin{array}{l}\text { The cargo bikes } \\
\text { are transporting } \\
\text { children \& goods } \\
\text { in Netherlands, } \\
\text { whereas these } \\
\text { modes are mainly } \\
\text { used for cargo } \\
\text { mobility in New } \\
\text { york and London. }\end{array}$ \\
\hline $\begin{array}{l}\text { Lenz and } \\
\text { Richle [9] }\end{array}$ & 2013 & Europe & $\begin{array}{l}\text { What is the key } \\
\text { obstacle in } \\
\text { implementing } \\
\text { cargo bikes for } \\
\text { delivery and the } \\
\text { potential areas } \\
\text { where it is used? }\end{array}$ & $\begin{array}{l}\text { The key challenge } \\
\text { of deploying cargo } \\
\text { bikes for daily } \\
\text { delivery is on } \\
\text { convincing } \\
\text { customer for cargo } \\
\text { bikes, as a suitable } \\
\text { mode and the } \\
\text { potential areas } \\
\text { where it can be } \\
\text { utilized are food, } \\
\text { courier, express } \\
\text { and parcel market. } \\
\text { (FCEP) }\end{array}$ \\
\hline $\begin{array}{c}\text { Riehle } \\
{[10]}\end{array}$ & 2012 & Europe & $\begin{array}{l}\text { What are the key } \\
\text { challenges of } \\
\text { using cargo } \\
\text { bikes/cycles for } \\
\text { end users/ } \\
\text { retailers? }\end{array}$ & $\begin{array}{l}\text { The key challenge } \\
\text { for improving the } \\
\text { usage of cargo } \\
\text { bikes are: the } \\
\text { perception of } \\
\text { customers (B2C), } \\
\text { to accept it as a } \\
\text { suitable mode. }\end{array}$ \\
\hline
\end{tabular}

But leveling the above challenges of urban mobility, cargo bikes were recommended as an optimal choice for last mile delivery [3]. An analytical report on cargo bikes [4], utilized by DHL express and Fedex revealed that there is no standard volume and dimensions for cargo bikes but it can be customized depends on the customer demand. The former one (DHL) implemented cargo bikes, with an intent of reducing carbon emission (16 tons/year) in Frankfurt city, just by limiting the cargo volume of bike $(125 \mathrm{~kg})$ whereas the latter one (Fedex), introduced the cargo bikes for quick delivery in Paris, with a higher speed (20-40 kmph) \& minimal cargo capacity (53 cubic feet). Moreover, the cities like: Los Angeles, Seattle (US), have restrictions on roadside parking (9 to 15 minutes) for cargo vans \& trucks and hence smaller cargo bikes were used frequently.

The cargo bikes were designed with an adaptive utility box, based on the nature of the cargo. If the cargo assigned had organic goods (such as food, dry fruits or sea foods etc), then the utility box needs air conditioning or thermal insulating layer for preserving it; whereas the cargo with courier packs (non-organic materials) are dispatched through special back-packs with a maximum load of $30 \mathrm{~kg}$. The following Table-1 gives the research works carried out in the area of cargo bikes in various cities in USA and Europe. The research objectives and the key results are separately given in the table. But, there is minimal exploration of this kind of research work in Asian countries such as India. Thus, a case study has been conducted in Bangalore city to explore the research questions given in the previous section.

A team of researchers [11] tested the efficiency of cargo bikes in a Portugal city, by two methods. In the first method, they did the on-road testing by comparing the performance (economic and environmental parameters) of cargo bikes with diesel vans. Economic efficiency was measured by road taxes, insurance cost, depreciation cost and energy cost whereas the environmental efficiency was measured by storage capabilities, travel limits, energy required per unit distance and carbon emission $\left(\mathrm{CO}_{2}\right)$. In the second method, the traffic flow was simulated by analysis tool (AIMSUN) using parameters namely: delay time, average speed, wheel to wheel energy consumption. The testing results suggested that: Cargo bikes performed better than cargo vans (Ist Method) and the optimal replacement value of diesel cargo vans by bikes would improve the traffic flow efficiency.

The processes involved in cargo delivery of e-retail firms have followed 3-steps and they are:

\section{a. Customer Order \& frequency:}

E-Commerce companies collect orders from two types of customers and they are: retailers and unit-volumers. Retailers were the shop owners of small-sized (revenue with less than INR 1 lakh/month) or medium-sized (revenue with INR 2 to 5 lakh/month) shops, who would place orders on processed and semi-processed goods through e-commerce companies. Their ordering frequency were mostly scheduled during the third \& fourth week of every month and the order quantity would be in the large volume. Unit-volumers were the salaried 
individuals and college students, preferred to place orders during the first and second week of every month and the order volume is low.

\section{b. Delivery flow:}

The cargo was delivered to the customers by using the following delivery flow pattern, Fig. 2, which consists of two stages. The delivery time of a product is the sum of the time taken on Stage-(1) \& (2). Stage-1 indicates the movement of cargo bikes from distribution centres to customer premises; whereas the stage- 2 indicates the time required for identifying the customer location and duration for payment processing. Payment processing time was considered for all post-paid deliveries, where payment is done through e-wallets.

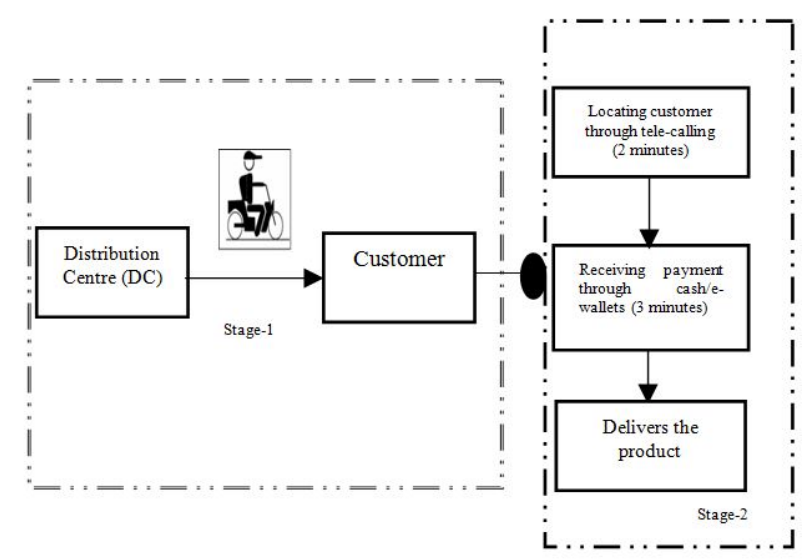

Figure 2. Delivery flow diagram

\section{c. Last mile Delivery pattern:}

The e-retailing firms had two delivery patterns for customers, depends upon the nature of the product (organic/inorganic) and the membership of customers (Premium/non-premium). Customers would be delivered on same day of order or on the next day (if the ordered time is after $12 \mathrm{PM}$ ), if they ordered the organic product (meat/fish) or they had premium membership. On the other way, if the customers ordered inorganic/stationary goods or if the end-user did not subscribe for memberships then they will receive the product within two to five business days.

\section{TRAFFIC SIMULATION MODEL}

The proportion of bike usage in Indian commercial sectors, perceives the rapid inflation in last 5 years. The effect of cargo bike usage is analyzed in this research work by using traffic simulation model.

Traffic models is an intelligent tool to identify optimum decisions of traffic environment [12] by estimating the effect of every decision, through simulation. This process helps decision maker of civil bodies to provide successful decision for implementing [13]. Traffic models are classified into three levels namely: Microscopic models, Mesoscopic models and Macroscopic models. Microscopic models describe the dynamic nature of vehicle behavior, according to the leading vehicle. The dynamic nature of vehicle includes the speed, acceleration and interspace between two vehicles. It also simulates [14] vehicle behaviors on four different conditions namely: Free driving zone (no influence of leading vehicle), approach zone (both lead and follow vehicle travels with same speed with less interspace), Following zone (Driver would have different speed patterns to maintain same interspace between both vehicles), braking zone (Drivers will reduce the speed from medium to negative speed, if the safety buffer space between vehicles were reduced). Two algorithms are used in this traffic models (Microscopic) and they are fixed value threshold and Wiedemann approach. The former algorithm determines the space between lead and follow vehicle, whereas the latter approach (i.e., wiedmann approach) calculates the driver behavior when the interspace between vehicles changes. PTV vissim software was sorted under microscopic model. Mesoscopic models are used to analyze the traffic in larger region with complex parameters [15]. These models are also used in tracking the mobility of larger vehicle fleet by using GPS/map location systems.

\subsection{Traffic Simulation Model Architecture}

Each Traffic models have three internal elements and they are manifested in the diagram (Fig.3).

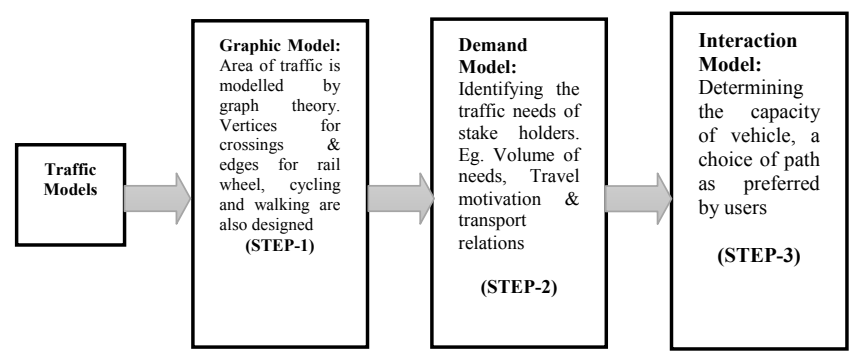

Figure 3. Architecture of traffic simulation model.

\section{DATA COLLECTION}

To measure the sustainable performance of bikes in relative with other modes, a survey was done with cargo bike drivers. The cargo bikes sustainability was measured by: Economic, Environmental \& social dimensions (Table-2). Economic performance was analyzed by: Operating cost, Maintenance cost, parking cost \& delivery time. Environmental performance was measured by determining the air, noise \& sound pollution values per unit distance. Social performance was measured by driver discomfort percentage, cargo carrying capacity, vehicle volume.

The data was collected in two stages. In the initial phase, it was collected by personal interview method. Five interviewees were participated where in three cargo bike drivers (Amazon, Flipkart) and two truck drivers (light \& heavy vehicles) shared their experiences. In the second phase, a video graphic study was done in a traffic dense roads and signals, to determine the vehicle composition and factors which improve the traffic flow speed.

A high traffic dense signal (St. Marks church signal) was identified in a city (Bangalore) of India. The data was recorded in two time zones (Peak \& Non-peak 
time). Time zone where students and office-goers preferred to travel, was labelled as peak time zone, whereas the occasional travel by passengers for picnic, hospitals \& worship places termed as non-peak time zone. Usually, peak time zone in bangalore was between 0730 to $1000 \mathrm{AM}, 0400$ to $0730 \mathrm{PM}$ and the rest of the time was considered as non-peak time zone.

Table 2: Data Recorded From The Cargo Drivers

\begin{tabular}{|c|l|l|}
\hline S.NO. & $\begin{array}{c}\text { CATEGORY } \\
\text { OF DATA }\end{array}$ & \multicolumn{1}{|c|}{ DETAILS OF DATA } \\
\hline 1. & $\begin{array}{l}\text { Economic } \\
\text { Performance }\end{array}$ & $\begin{array}{l}\text { Delivery time of cargo during } \\
\text { peak time periods; Operating } \\
\text { cost, maintenance cost, } \\
\text { parking cost of cargo vehicles } \\
\text { within city }\end{array}$ \\
\hline 2. & $\begin{array}{l}\text { Environmental } \\
\text { performance }\end{array}$ & $\begin{array}{l}\text { Air pollution (CO, PM, NOx, } \\
\text { HC+NOx), Noise pollution } \\
\text { (Vibration in X-axis, Y-axis \& } \\
\text { Z- axis \& Noise in decibels. })\end{array}$ \\
\hline 3. & $\begin{array}{l}\text { Social } \\
\text { Performance }\end{array}$ & $\begin{array}{l}\text { Driver discomfort, Cargo } \\
\text { capacity \& Volume of } \\
\text { vehicles per minute }\end{array}$ \\
\hline
\end{tabular}

The interviewing process with cargo bike dealers manifested three key information and they were:

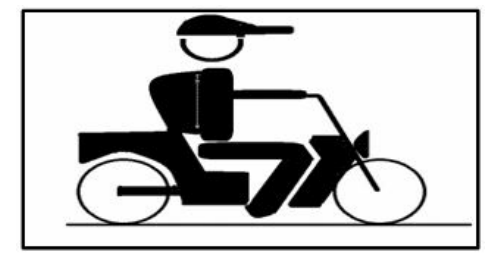

Figure 4: Cargo Bike driver's sitting pose

- The parcel size was the primary factor for determining the mode of transport by logistic planners. If the parcel size was between 0.2 to $0.4 \mathrm{~kg}$ (Type-1); then the preferred mode is cargo bike whereas the parcel size was 0.5 to $1.0 \mathrm{~kg}$ (Type-2), then minitrucks/cargo van, would be used.

- Attainable target set by logistic planners for cargo bikes/trucks were 100 to 120 packets (Type-1/Type-2) per day (Table-3) and the monetary incentives were INR 1000 to 1500 per day (Cargo bikes); INR 1500 per day (Light vehicles); INR 2000 per day (Trucks).

- Driver discomfort was a dynamic variable based on the vehicle used. For instance: Cargo bike drivers had to travel seamless drive for six to eight hours of ride and hence, they preferred wrong sitting pose (i.e., Head and neck inclined towards forward with a C-bend) and it eventually develops back pain and shoulder pain. But the perfect sitting (Fig.-4) pose (without C-bend in spinal cord) is shown in the small art. Moreover, the drivers of trucks/cargo vans, had visual and hearing troubles because of late night driving and high decibel engines.

\section{DATA ANALYSIS}

The initial phase was executed by systematic process to determine the sustainable [16] performance of every modes (bikes, light vehicles \& trucks). The raw data collected from cargo drivers are drivers travel limit per day, driver cost, maintenance cost \& mileage of vehicle (economic performance domain); Driver discomfort percentage, cargo capacity (Social performance). Subsequently the processed data are: Operating cost, Cost of fuel [by market rates] (Economic domain); air pollution [17] [ARAI table], Noise pollution [Vibration sensors along with android apps] (Environmental domain); peak time vehicle volume \& non-peak time vehicle volume by video graphic study (Social performance).

Based on the observations (Table-3), cargo bikes (A) need lower operating cost (i.e.,) It (A) needs one-half [Rs.13.24/km] of light vehicles' cost [Rs.28.03/km] and also it (A) needs just less than one-fourth of heavy vehicle (Rs.61/km). The economic performance data were also plotted in figure (Fig.7). Moreover, the air pollution data was derived from ARAI tested results of two and four wheelers. The results manifested (fig.8), that cargo bikes and light vehicles had equivalent proportion of emission whereas the trucks emission were exponentially higher than cargo bikes and trucks. Noise and vibration vales were observed by vibration sensors of smart phone (enabled with validated Bosch software). Vehicle composition (Table-4) was defined as the count of various vehicles (Bikes, Light vehicles \& heavy vehicles) on the road, during the specific time (peak/non-peak time).

In the second phase, a video graphic data was recorded in a traffic dense signal (St.Marks signal) for 10 minutes on all lanes, The signal junction was intersected with seven lanes (Fig.5) wherein forward lanes were: 1,3,4,7 and backward lanes were:2,5\&6. These lanes were served as key link between amazon distributions centers and customers (residential \& commercial) though it was not a dedicated lane, for cargo travel.
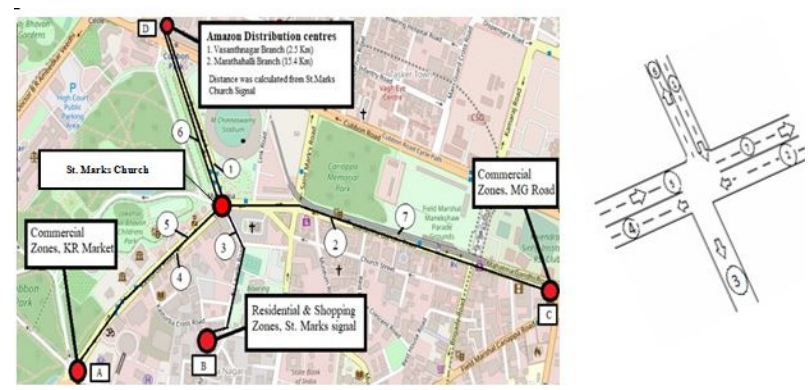

Figure 5: Road Layout (blue print) of St. Marks signal with locations of distributor and customers

The video graphic study revealed that light vehicles (Table-4) are the major road user $(55.7 \%)$ followed by bikes (37.04\%) and heavy vehicles (7.2\%).

The key process involved in video graphic study was recorded in the flow chart (Fig.6).

The data derived from video graphic study are: volume of vehicles, no. of lanes in every route and vehicle composition. It was then fed into the software tool (PTV Vissim software), for analysis [18]. This software tool (Fig.7) needs certain inputs on lane width, curvature of each lanes on diversions and the traffic signal timings to provide smart solutions by simulating traffic flow, estimating vehicle speed $\&$ travel time. 
Table 3: Micro-level economic performance measurement index

\begin{tabular}{|c|c|c|c|c|c|c|c|}
\hline $\begin{array}{c}\text { VEHICLE } \\
\text { TYPES }\end{array}$ & $\begin{array}{c}\text { DRIVER'S } \\
\text { TRAVEL LIMIT } \\
\text { PER DAY WITHIN } \\
\text { CITY } \\
\text { (A) }\end{array}$ & $\begin{array}{c}\text { DRIVER'S } \\
\text { SALARY (INR) } \\
\text { PER DAY } \\
\text { (B) }\end{array}$ & $\begin{array}{c}\text { DRIVER'S } \\
\text { COST (INR) } \\
\text { PER KM } \\
\text { (C) }\end{array}$ & $\begin{array}{c}\text { COST OF } \\
\text { FUEL IN INR } \\
\text { PER LITRE } \\
\text { (D) }\end{array}$ & $\begin{array}{c}\text { MILEAGE } \\
\text { ATTAINED PER } \\
\text { LITRE IN KM } \\
\text { (E) }\end{array}$ & $\begin{array}{c}\text { RUNNING COST } \\
\text { INR PER KM) } \\
\text { (F) }\end{array}$ & $\begin{array}{c}\text { TOTAL } \\
\text { OPERATING } \\
\text { COST IN INR } \\
\text { (7) (G) }\end{array}$ \\
\hline $\begin{array}{c}\text { Cargo Bikes } \\
\text { (Gasoline) }\end{array}$ & $80-90 \mathrm{Km}$ & 1000 & 11.76 & 74 & 50 & 1.48 & 13.24 \\
\hline $\begin{array}{c}\text { Light vehicle } \\
\text { (Mini Trucks) }\end{array}$ & $60 \mathrm{Km}$ & 1500 & 25 & 50 & $15-18$ & 3.03 & 28.03 \\
\hline Heavy Vehicle & $30-40 \mathrm{Km}$ & 2000 & 50 & 50 & $7-10$ & 8.5 & 61 \\
\hline
\end{tabular}

Table 4: Vehicle Composition details on each route

\begin{tabular}{|c|c|c|c|c|}
\hline \multirow{2}{*}{$\begin{array}{l}\text { ROUTE } \\
\text { (From- } \\
\text { To) }\end{array}$} & \multirow{2}{*}{$\begin{array}{l}\text { DETAILS } \\
\text { OF } \\
\text { SIGNAL } \\
\text { RUNNING } \\
\text { TIME } \\
\text { (Sec) }\end{array}$} & \multicolumn{3}{|c|}{$\begin{array}{l}\text { PERCENTAGE OF VEHICLES } \\
\text { ON THIS ROUTES }\end{array}$} \\
\hline & & $\begin{array}{c}\text { Two } \\
\text { wheelers }\end{array}$ & $\begin{array}{c}\text { Light } \\
\text { vehicles }\end{array}$ & $\begin{array}{c}\text { Heavy } \\
\text { vehicles }\end{array}$ \\
\hline $1-3$ & 20 & $32.7 \%$ & $67.21 \%$ & $0 \%$ \\
\hline $1-4$ & 120 & $30.7 \%$ & $69.23 \%$ & $0 \%$ \\
\hline $1-7$ & $\begin{array}{c}\text { Free left } \\
(120)\end{array}$ & $0 \%$ & $75 \%$ & $25 \%$ \\
\hline $2-3$ & $\begin{array}{l}\text { Free left } \\
(120)\end{array}$ & $51.6 \%$ & $48.38 \%$ & $0 \%$ \\
\hline $2-4$ & 120 & $50 \%$ & $47.05 \%$ & $2.9 \%$ \\
\hline $2-6$ & 30 & $36.11 \%$ & $60.5 \%$ & $3.4 \%$ \\
\hline $5-6$ & $\begin{array}{l}\text { Free left } \\
(120)\end{array}$ & $44.8 \%$ & $34.48 \%$ & $20.6 \%$ \\
\hline $5-7$ & 120 & $50.47 \%$ & $43.80 \%$ & $5.71 \%$ \\
\hline \multicolumn{2}{|c|}{ Average $=$} & $37.04 \%$ & $55.7 \%$ & $7.20 \%$ \\
\hline
\end{tabular}

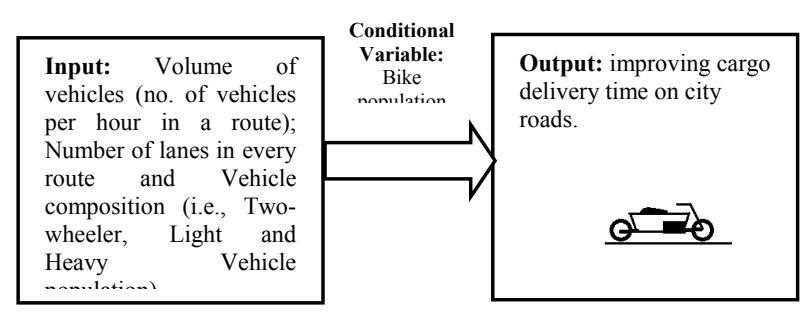

Figure 6: Inputs \& Outputs Of Ptv Vissim

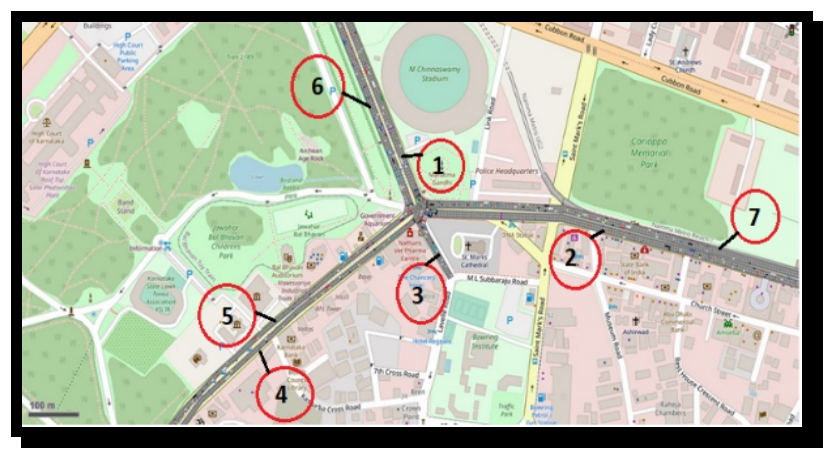

Figure 7: Simulated Road Layout With Vehicles

The data analysis was executed by varying (conditional variables) compositions of bike population (i.e.,) raw data value (37.04\%), +10\% (47.04\%), +20\% $(57.04 \%),+30 \%(67.04 \%)$ and the output estimated as vehicle travel time.

\section{RESULTS}

The economic performance graph (fig.-8) responded to the former part of the research query: "Cargo bikes sustainable performance within the scope of economic, environmental and social dimensions". The cargo bikes consumed only $68 \%(9.1 \mathrm{~min} / \mathrm{km})$ of truck's delivery time $(13.35 \mathrm{~min} / \mathrm{km})$. Moreover, cargo bikes outperformed the other vehicle's economic dimension. \{Operating cost (Rs.13.24/km), Maintenance cost (Rs.10/km) and Parking cost (Rs.0.5 / km)

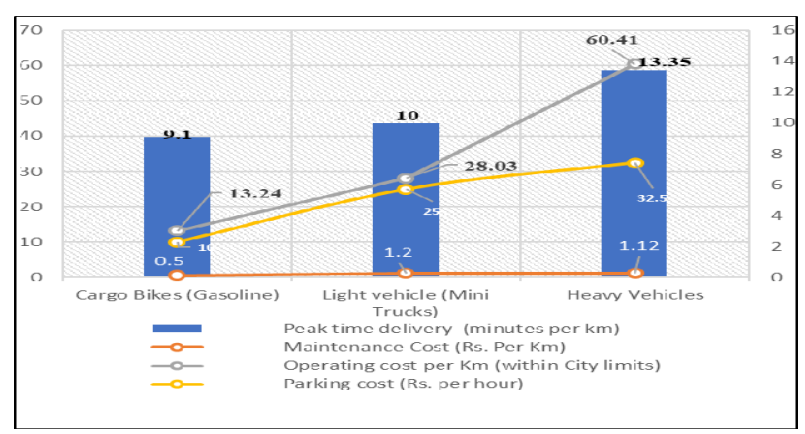

Figure 8: Vehicle's Economic Performance

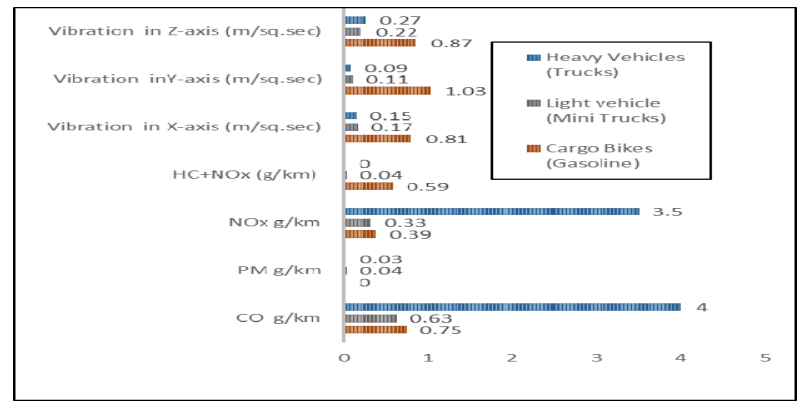

Figure 9: Vehicle's Environmental Performance

The environmental performance graph (fig.9), investigated the parameters, namely: air pollution, noise \& vibration generated by every vehicle, on city traffic roads. Air pollution was measured by measuring carbon monoxide $(\mathrm{CO})$, particulate matter $(\mathrm{PM})$, nitric oxide (NOx), sum of hydrocarbons and nitric oxide ( $\mathrm{HC}+\mathrm{NOx})$ and these values were measured in $\mathrm{g} / \mathrm{km}$ respectively. Vibration frequency was measured by sensors attached to a smart phone (android app validated with Bosch). It measured the vibration in three dimensions $(\mathrm{X}, \mathrm{Y}, \mathrm{Z})$ and its average was plotted. Cargo bikes had low air pollution \{CO-18.75\% (ie., $0.75 \mathrm{~g} / \mathrm{km}$ ); NOx-11.14\% (ie., 0.39 $\mathrm{g} / \mathrm{km})$, PM $(0 \%)$ relative to the trucks whereas the vibration frequency of noise is higher for cargo bikes and it is measured in meters per square second.

The third dimension (vehicle social performance) of cargo bikes performance analysis was recorded in the figure (fig.10). Social performance of vehicles was measured by: percentage of driver discomfort, cargo 
carrying capacity of vehicles, peak time vehicle volume on roads and non-peak time vehicle volume on roads. Driving discomfort was measured by the effects (pain/fatigue) of driving on driver and the values were captured for the scale of 100 .

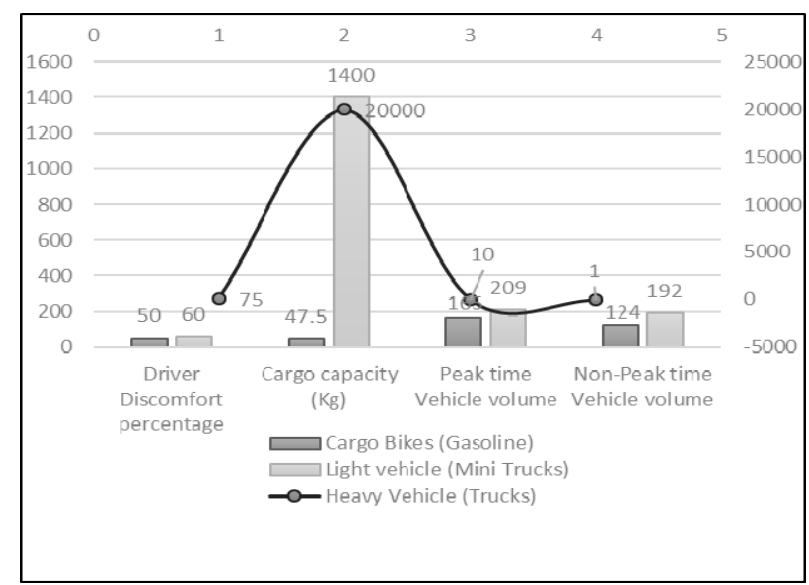

Figure-10: Vehicle's Social Performance

Cargo bikes driving discomfort is just $66 \%$ of truck drivers, whereas cargo lifting capacity is lowest for cargo bikes (ie., it can transport $0.2 \%$ of truck's cargo and $3 \%$ light vehicle's cargo). Peak time vehicle volume and nonpeak time vehicle volume is lower for trucks and higher for light vehicles, whereas the cargo bike volumes are moderate. (ie., Cargo bike volume (292) 66\% of light vehicles (440) during peak hour-Fig.11).

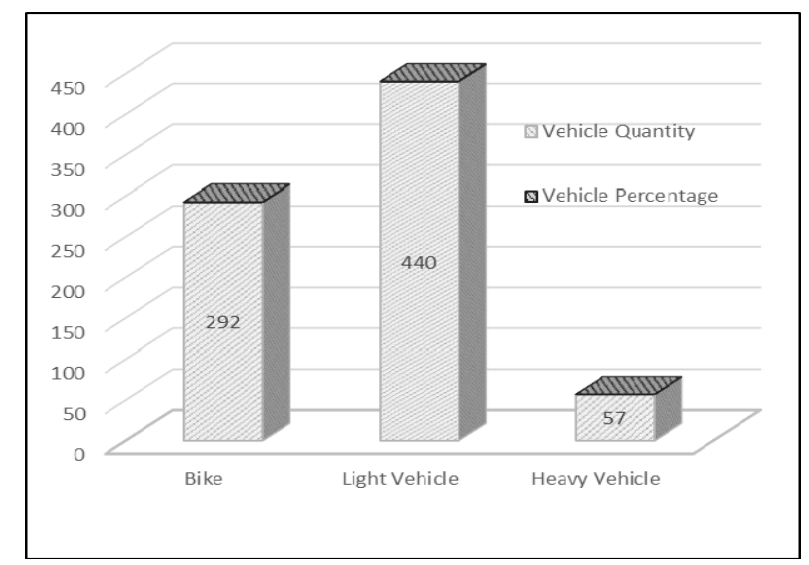

Figure-11: Vehicle's Composition On City Roads

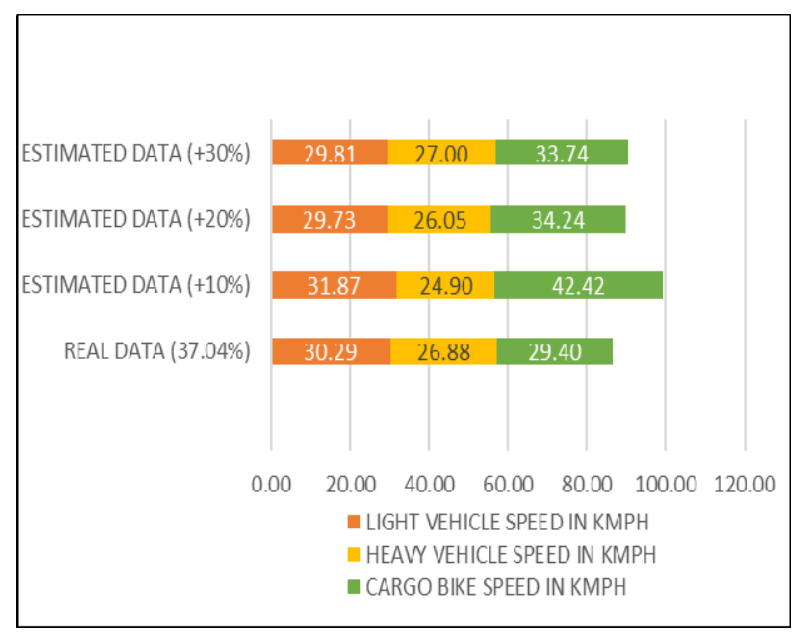

Figure-12: Estimation Of Vehicle Travel Speed, Within City Limits For Conditional Varibles
Based on the software output (PTV Vissim) a bar chart was constructed (Fig.12). The plot manifests the relationship of vehicle composition with vehicle speed. The sample size of vehicles observed was 789. The bar chart manifested that cargo bike (smaller dimension \& moderate composition) has max. speed (30.29 kmph); followed by trucks (lower vehicle composition \& larger dimension) that have optimum speed $(29.40 \mathrm{kmph})$ and eventually by light vehicles of lower speed (26.88 kmph).

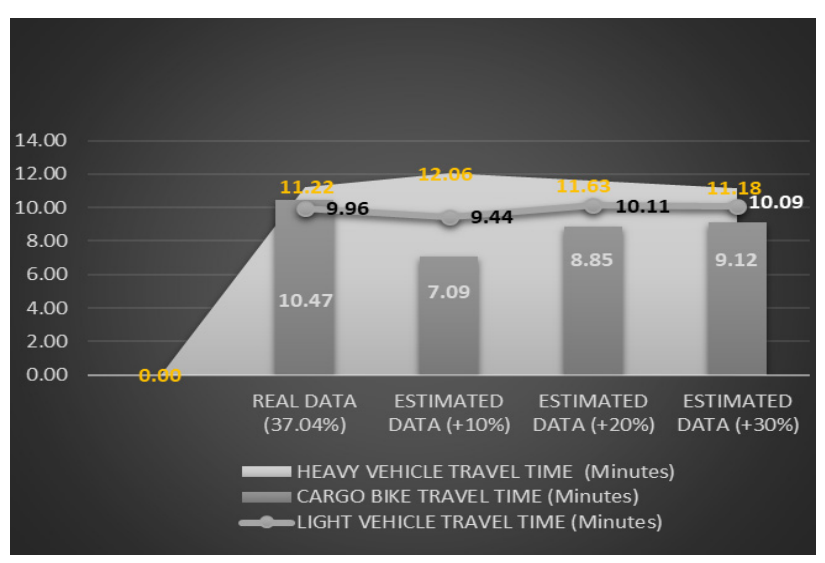

Figure-13: Estimation Of Vehicle Travel Time, Within City Limits By Increasing Cargo Bike Count In Roads

The numerical output was translated into graphical output (Fig.13) and analyzed. The graphical output (Fig.12 \&13) was providing evidence for the second part of the research query: "Limit of Significance in key factors which influences the cargo delivery time". The plots expressed the optimum bike compositions to maximise the travel time of cargo bikes. The tried iterations are $+10 \%,+20 \%,+30 \%$ of original (raw) data. The estimated lowest travel time (7.09 minutes) attained by cargo bikes will be at optimum $(+10 \%)$ bike populations.

The inferred results from the above plot (figure-11) are as follows.

a). For cargo bikes: Travel speed is directly proportional to the altered conditional variable ie., travel speed increases to $69.3 \%$ (42.42 $\mathrm{kmph}), 85.86 \%$ and $87.13 \%$ in par with its original speed $(29.40 \mathrm{Kmph})\}$.

b) For light vehicles: Travel speed is randomly varying with the altered conditional variable \{ie., travel speed increases to $5.21 \%(31.87 \mathrm{kmph})$, and then decreases to $-1.84 \%$ (29.73 kmph) and $-1.584 \%$ (29.81 kmph).

c). For heavy vehicles: Travel speed declines with the altered conditional variable, \{ie., travel speed reduces to $-7.4 \%$ (24.90 $\mathrm{kmph}),-3.08 \%$ (26.05 $\mathrm{Kmph})$ and $+0.5 \%(27 \mathrm{Kmph})$ in par with its original speed (26.88 Kmph)\}.

Vehicle travel time's estimated values are captured in the above graph (Fig.-13). Vehicle travel time is calculated by the ratio of vehicle speed to the distance travelled and hence the gradient of vehicle travel time graph follows the same pattern as like vehicle speed.

\section{DISCUSSION:}

To comprehend the potential reasons for selecting cargo bikes as optimum mode within city limits, the above survey was conducted. Sixteen parameters were identified under three major dimensions (Economic, 
environmental and social performance). Cargo bikes outperforms other vehicles in twelve parameters wh0ereas it performs modestly in rest four parameters. The underperformed parameters were: Vibrational frequency in three axis and emission of hydrocarbon.

Vibrational frequency was higher for cargo bikes because of its single-tier suspension system, whereas light vehicles and trucks had leaf springs and hydraulic suspensions. Hydrocarbon emissions were higher in cargo bikes, as it took longer ride in lower gears during traffic peak hours. It eventually led to incomplete combustion.

Table 5 Validation of Simulation tool (PTV vissim)

\begin{tabular}{|c|c|c|c|c|}
\hline \multirow[b]{2}{*}{ SNO } & \multirow[b]{2}{*}{$\begin{array}{l}\text { Vehicle } \\
\text { Types }\end{array}$} & \multicolumn{2}{|c|}{$\begin{array}{l}\text { Vehicle Travel time } \\
\text { during peak hours }\end{array}$} & \multirow[b]{2}{*}{$\begin{array}{c}\text { Percentage of } \\
\text { deviation } \\
\{(\mathrm{A}-\mathrm{S}) / \mathrm{A}\}\end{array}$} \\
\hline & & $\begin{array}{l}\text { Actual data } \\
\text { (A) from } \\
\text { city roads }\end{array}$ & $\begin{array}{l}\text { Simulated } \\
\text { data from } \\
\text { PTV vissim } \\
\text { (S) }\end{array}$ & \\
\hline 1. & $\begin{array}{c}\text { Two- } \\
\text { Wheeler }\end{array}$ & 9.1 & 9.35 & $2 \%$ \\
\hline 2. & $\begin{array}{l}\text { Light } \\
\text { vehicles } \\
\text { (Mini } \\
\text { trucks) }\end{array}$ & 10 & 9.96 & $0.40 \%$ \\
\hline
\end{tabular}

Moreover, the second stage analysis was done in PTV vissim to identify the factors which can improve the delivery time. Based on the analysis, the optimum addition ( $10 \%$ of cargo bike) to the existing traffic volume (bangalore) will improve the vehicle speed and delivery time of cargo by the bike mode $(69 \%)$ and light vehicle mode $(5 \%)$, within the city roads during peak hours. Finally, the calibration of tool (Vissim) was done with the actual survey values. The percentage of deviation (Table-5) was less than five percent (Cargo bikes \& Light vehicles) and fifteen percent for heavy vehicles.

The simulated data attained from the PTV Vissim software was validated by the real time data for the two class of vehicles (Two wheelers and Light vehicles). The deviation percentage for the both categories are within 5\%. Therefore, the results of this tool (PTV Vissim) attained are consistent and reliable for further processing. Hence, it can be an optimum tool to study the traffic.

\section{CONCLUSION:}

The outcomes of the survey and the traffic simulator have given the significant motives (sustainable solution) of e-retail firms, for favoring the cargo bikes in the last mile delivery. The observations have suggested the following recommendations and they are:

Each cargo bike driver was assigned with 100 to 120 nos of type- 1 boxes per day, depending upon the orders received on that day. To improve the delivery quantity (40-50 nos) further, the weight of the (type-1) box have to be lessened, by reducing or eliminating multiple layers of packing inside a box.

The mobility cost of a cargo parcel $/ \mathrm{km}$ through cargo bikes (Rs.23.74) is almost one half of minitrucks (Rs.54.23). Therefore, cargo bikes may also be preferred for other (type-2) parcel boxes too, to trim the overload expenses. It can be achieved by modifying the cargo bikes dimensions and it can be effective only by strategic alliances between logistic planners and automobile manufacturers.

Subsequently, the payment processing time (postpaid orders) after delivery consumes three minutes for the customers who prefer to pay through online wallets. Therefore, e-retail firms have to encourage their customers for prepaid orders, to shrink the delivery time by twenty percent.

Training and workshops, after recruiting drivers, have higher probability of improving the productivity (delivery speed) namely: knowledge on available shortcuts within urban areas (low preferred roads), signal counter timings on traffic-dense roads, non-peak time zones of every regions. E-retail firms have to encourage its cargo drivers to prefer ungeared vehicles for city drives, which can increase the driver comfort.

Moreover, an e-retail firm in China (Alibaba), has been using dedicated routes within urban and on country sides. Based on these benefits, the firm is paying toll for the federal agencies. These practices can accelerate the delivery rate and time in India too, if it is implemented. It can be possible by partnering with city authorities and urban planners. The probable outcomes of this partnership would be: dedicated routes, reserved parking spaces for cargo bikes, allotted spaces within cities for developing distribution centers and charging stations.

In addition, cargo bikes utility sphere can also be enlarged by using it in both first mile and reverse logistics (returned orders, collecting carton boxes for reusing) too, instead of refrained usage in the last mile. The results and implications of this article can also be further extended for multiple urban areas of India, with alternative fuel-run $[19,20]$ cargo bikes.

\section{ACKNOWLEDGEMENT}

We acknowledge the support of traffic police personal of St.Mark's signal, Bangalore, India for permitting the researcher to observe readings during peak and nonpeak hours for several iterations.

\section{REFERENCES}

[1] David Kriger et al, text book named "Traffic engineering Handbook"-7th edition; Chapter-6 titled, "Forecasting Travel demand" DOI: 10.1002/ 9781119174738

[2] Wang.Y, Jiang.X, Lee.L.H, Chew.E.P, Tan.K.C (2017), "Tree based searching approaches for integrated vehicle dispatching and container allocation in a transshipment hub", Experts application:Vol.74;pp:139-150.

[3] European cycle logistics federation conference (2014) "Cycle logistics federation" published in 30 July 2017; http://eclf.bike/about.html

[4] https://doi.org/10.1016/j.eswa.2017.01.003

[5] Manali sheth, Poline butrina, Anne goodchild, Edward McCormack, "Measuring delivery route cost trade-off's between the electric assist cargo bicycles and delivery trucks in dense urban areas", European transport research review (2019) 11:11; https://doi.orf/10.1186/s12544-019-0349-5. 
[6] Handy S.L, Boarnet M.G., Ewing. R, Killingsworth R.E. (2002), "How the built environment affects physical activity", America Journal of preventive medicine 23 (25), pp.64-73

[7] Melo S (2011), "Evaluation of urban goods distribution initiatives: an empirical overview in the Portugal context. IN:Machari.C.Melo S(eds) city distribution and urban freight transport, Edward elgar, Cheltenham pp. 234-260

[8] F. Arnold, I. Cardenas, K. Sorenson, W. Dewulf (2018), "Simulation of B2C e-commerce distribution in Antwerp using cargo bikes and delivery points:"; European Transport research review 10(1).

[9] Choubassi. C (2015), "an assessment of cargo cycles in varying urban contexts" PhD thesis, University of Texas;

[10] Lenz. B, Riehle E. (2013), “Bikes for urban freight transportation research record", Journal for Transportation Research Board, HTTP:/DX.DOI.ORG /10.3141/2379-05.

[11] Riehle E. (2012), Das lastenfaherad als transportmuttel fiir stadtischen wirtchafts verkehr (master thesis)

[12] Melo S., Baptista. P, Costa. A. (2014), “Comparing the use of small-sized electric vehicles with diesel vans on city logistics", Procedia Social Behavior Sciences

[13] Marianna Jacyna et al, (2017), "Modelling of Bicycle Traffic in the cities using Visum", Proceedings of 10th International scientific conference Transbaltica, 2017: Transportation Science and Technology, 187 (2017): 435-441.

[14] H,Macmassani, “Dynamic network traffic assignment and simulations methodology for advanced system management applications", Network Spatial economy. 1(2001):267-292

[15] Chalmers (2014), Civil and environmental engineering, Master's thesis pp. no:5-14

[16] Elefteriadou L (2014), “Assessment of car following models by driver type and under different traffic, weather conditions using data from an instrumented vehicle", Simulation modelling practice and theory, DOI:10.1016/ j.simpat.2013.10.002

[17] Francesco et al, proceedings of "City characteristics and urban goods movements: A way to environmental transportation system in a sustainable city", procedia-social and behavioral sciences 39 (2012):61-73; doi: 10.1016/j.sbspro.2012.03.091

[18] ARAI (2018), “Indian Emission Regulation Booklet", available on https://www.araiindia.com/pdf /Indian_Emission_Regulation_Booklet.pdf

[19] H. Macmassani, "Dynamic network traffic assignment and simulations methodology for advanced system management applications", Network Spatial economy. 1(2001):267-292

[20] Schliwa G et al (2015), "Sustainable city LogisticsMaking cargo cycles viable for urban freight transport", Research in transportation business and management, http://dx.doi.org/10.1016/j.rtbm.2015 .02 .001

[21] Browne. M, Allen. J., Leonardi. J. (2011), Evaluating the use of an urban consolidation centre and electric vehicles in central London, IATSS research 35(1);

\section{ОДРЖИВЕ ПЕРФОРМАНСЕ ТЕРЕТНОГ \\ БИЦИКЛА У ЦИЉУ СКРАЋЕЫА ВРЕМЕНА ДОСТАВЕ РОБЕ ПРИМЕНОМ МОДЕЛА СИМУЛАЦИЈЕ САОБРАһАЈА}

\section{Б. Рајеш П, Џ. Рајан А}

Сектор урбаног транспорта робе у Индији од 2011. године доживљава експоненцијални раст коришћења теретних бицикала за доставу робе купцима. Мала е-предузећа користе теретне бицикле због мобилности на друмовима оптерећеним саобраћајем. Рад представља допринос одрживом развоју е-трговине и мери економски, еколошки и социјални учинак теретних бицикала применом методе истраживања. Проучава се оптималан број бицикала на градским улицама у циљу брзе и благовремене испоруке робе. Подаци добијени видео графичком студијом анализирани су алатом PTV Vissim за симулацију саобраћаја. Евалуација резултата је извршена коришћењем реалних података. Налази истраживања треба да помогну да теретни бицикли замене мале камионе, што скраћује време испоруке робе, смањује емисију угљеника и побољшава комфор возача. Такође, е-предузећа треба да мотивишу купце да користе припејд наруџбине и доставу робе ван шпица у циљу побољшања одрживости. 